\title{
Pengaruh Latihan Kekuatan terhadap Restless Legs Syndrome Pasien Hemodialisis
}

\author{
Anggriyana Tri Widianti' ${ }^{1}$, Yanti Hermayanti², Titis Kurniawan ${ }^{2}$ \\ ${ }^{1}$ STIKes Aisiyah, Bandung, ${ }^{2}$ Fakultas Keperawatan, Universitas Padjadjaran \\ Email: anggriyana19januari@gmail.com
}

\begin{abstract}
Abstrak
Restless legs syndrome (RLS) adalah gangguan sensorimotor yang banyak terjadi pada pasien hemodialisis (HD). Terapi farmakologi merupakan pilihan utama penanganan RLS yang justru berisiko menimbulkan efek samping. Optimalisasi fisik pasien HD melalui latihan kekuatan dinilai berpotensi efektif memperbaiki restless legs syndrome. Belum terdapat penelitian yang mengklarifikasi pengaruh latihan kekuatan terhadap RLS. Penelitian ini bertujuan untuk mengidentifikasi pengaruh latihan kekuatan terhadap skala RLS pada pasien HD di Unit Hemodialisis di RS Margono Soekardjo dan RSUD Banyumas. Metode quasi eksperimen dengan pre-post test with control group design ini menggunakan sampel sebanyak 32 pasien HD ( 15 pasien intervensi dan 17 pasien kontrol) dengan teknik cluster random sampling. Cluster random sampling dalam penelitian ini adalah penggunaan tempat penelitian sebagai kelas, yaitu satu rumah sakit untuk intervensi dan rumah sakit lainnya digunakan untuk kontrol. Latihan kekuatan pada ekstremitas atas dan bawah diberikan 2 minggu sekali saat proses hemodialisis berlangsung selama 8 minggu. Skala RLS diukur menggunakan IRLS Scale. Data yang terkumpul dianalisis menggunakan uji t tidak berpasangan. Hasil penelitian menunjukkan bahwa tidak terdapat perbedaan antar kelompok dari usia, ureum, adekuasi, lama HD, jenis kelamin, penyakit kormobid maupun penggunaan obat. Antar kelompok memperlihatkan terdapat perbedaan nilai TIBC $(p=0,000)$. Skala RLS kelompok intervensi menunjukan perbaikan dengan selisih mean -1 yang menandakan penuruan skala, adapun pada kelompok kontrol justru terlihat peningkatan kondisi RLS dengan selisih mean 1,29. Analisis antar kelompok terlihat signifikansi berbeda $(p=0,035)$ yang menunjukkan terdapat pengaruh latihan kekuatan terhadap skala RLS. Latihan kekuatan penting sebagai bagian dalam pengelolaan pasien uremik RLS.
\end{abstract}

Kata kunci: Latihan kekuatan, restless legs syndrome, skala RLS.

\section{Effect of Strength Training on Restless Legs Syndrome: Hemodialysis patients}

\begin{abstract}
Abstrac
Restless legs syndrome (RLS) is a sensorimotor disorder that occurs mostly in hemodialysis (HD) patients. Pharmacological therapy is the main choice of RLS treatment that is at risk of side effects. Physical optimization of HD patients through strength training was considered as potentially effective to fix restless legs syndrome. No research has yet clarified the effect of strength training on RLS. Therefore, this study aims to identify the effect of strength training on RLS scale on HD patients in Hemodialysis Unit at Margono Soekardjo Hospital and Banyumas Hospital. The quasi experimental method with pretest and posttest with control group design was applied to 32 samples of HD patients (15 intervention patients and 17 control patients) by applying cluster random sampling technique. Cluster random sampling in this study is the use of research place as a class, for instance, one hospital for intervention group and the other one used for control group. Strength training on the upper and lower extremities is given every 2 weeks when the hemodialysis process lasts for 8 weeks. The RLS scale is measured using IRLS Scale. The collected data were analyzed using unpaired test. The results showed that there were no differences between groups of age, urea, adequacy, duration of HD, gender, comorbid disease and drug use. The inter-group showed that there is a difference in TIBC value $(p=0,000)$. The RLS scale of the intervention group shows improvement with the mean difference of -1 indicating the scaling of the scale, while in the control group, it is seen an increase in RLS condition with a mean difference of 1.29. Inter-group analysis showed different significance $(p=0,035)$ indicating that there is a significant influence of strength training to RLS scale. Thus, strength exercise is important as part of the management of uremic RLS patients.
\end{abstract}

Keywords: Restless legs syndrome, RLS scale, strength exercise. 


\section{Pendahuluan}

Gagal ginjal merupakan hasil kerusakan fungsi dan struktur ginjal secara progresif. Gagal ginjal kronik (GGK) akan berkembang progresif menjadi gagal ginjal terminal atau end stage renal disease (ERSD) dan membutuhkan renal replacement therapy seperti dialisis dan transplantasi ginjal (CDC, 2014). Berdasarkan data The Global Burden of Disease tahun 2010, GGK menduduki peringkat ke-18 dalam daftar penyebab mortalitas dari sejumlah angka kematian global yaitu 16,3 per 100 ribu (Lazano et al., 2012). Data dari Persatuan Nefrologi Indonesia (PERNEFRI) diperkirakan terdapat 70 ribu penderita gagal ginjal di Indonesia, angka ini akan terus meningkat sekitar 10\% setiap tahunnya (Tandi, Mongan, \& Manopo, 2014). Berdasarkan data Pernefri (2014), jumlah pasien GGK di Jawa Tengah mencapai 1793 dan menduduki peringkat ke-3 setelah Jawa Barat dan Jawa Timur. Salah satu upaya penatalaksanaan yang dilakukan pada pasien GGK adalah dialisis (Baredero et al., 2005). Tahun 2014, Jawa Tengah menduduki peringkat ke-4 dengan jumlah pasien hemodialisa sebanyak 3362 (Pernefri, 2014).

Meskipun hemodialisis sangat membantu pasien GGK, namun terapi ini juga berisiko menimbulkan komplikasi yaitu salah satunya komplikasineurologi(Özkan\&Ulusoy, 2011). Komplikasi gangguan neurologi penting karena memengaruhi pasien hemodialisis dan meningkatkan morbiditas dan mortalitas pasien (Rizzo et al., 2012). Komplikasi gangguan neurologi yang dapat terjadi pada pasien hemodialisis adalah gangguan pergerakan dan restless leg syndrom (RLS) (Brouns \& Deyn, 2004). Restless leg syndrom pada pasien hemodialisis dapat menyebabkan komplikasi baru lagi bagi pasien hemodialisis seperti gangguan tidur dan depresi yang akan menurunkan kualitias hidup pasien. Angka RLS cukup tinggi pada pasien hemodialisis jika dibandingkan populasi umum (Brouns \& Deyn, 2004).

Restless legs syndrome (RLS) merupakan gangguan sensorimotor yang ditandai dengan keinginan untuk menggerakkan kaki dan diklasifikasikan kedalam gangguan pergerakan neurologi yang menimbulkan ketidaknyamanan rasa nyeri, gatal, seperti ada yang merayap di bagian yang terkena (Symvoulakis, Anyfantakis, \& Lionis, 2010; RLS Foundation, 2008). Jaber et al. (2011) melaporkan jumlah pasien hemodialisis yang mengalami RLS sebanyak $40 \%$ dari 235 responden. Munculnya RLS pada pasien hemodialisis menurunkan kualitas hidup. Sebagai konsekuensinya, kebanyakan pasien dengan RLS mengalami gangguan tidur, kecemasan, dan gejala depresi. RLS juga teridentifikasi sebagai salah satu penyebab pemberhentian proses hemodialisis serta meningkatkan risiko gangguan kardiovaskuler (RLS Fondation, 2008).

Beberapa studi juga merekomendasikan penatalaksanaan RLS menggunakan terapi nonfarmakologi. Penatalaksanaan RLS yang telah dilakukan belum sepenuhnya mengurangi keparahan RLS. Penelitian menunjukan latihan fisik terbukti aman, dan low-cost dalam menurunkan skala keparahan RLS (Giannaki et al., 2010). Efek latihan fisik pada RLS sebanyak 34\% menurunkan gejala RLS, juga menjadi pendekatan terapi nonfarmakologi yang mengadaptasikan fisik dalam peningkatan kualitas hidup (Johansen, 2012).

Meskipun hemodialisis dapat meningkatkan survival pasien GGK, penatalaksanaan hemodialisis tersebut tidak dapat berdiri sendiri dalam meningkatkan kualitas hidup pasien. Beberapa penelitian menunjukan berkurangnya kualitas hidup pasien setelah lama menjalani hemodialisis. Hal ini dihubungkan dengan efek hemodialisis pada penurunan struktur dan fungsi otot yang merupakan hasil dari uremia. Sehingga menyebabkan berkurangnya aktivitas fisik, atrofi otot, dan kesulitan dalam berjalan, kemampuan kerja fisik, dan fungsi yang lemah (da-Silva, 2013). Karena keterbatasan pasien dalam melakukan aktivitas harian dan inaktivitas sehingga dibutuhkan pengelolaan berupa peningkatan aktivitas fisik pasien seperti program latihan fisik.

Exercise atau latihan fisik pernah dilaporkan sebelumnya, dapat menurunkan keparahan RLS. Aerobic exercise terbukti dapat mengurangi gejala RLS. Hal ini dilakukan oleh Mortazavi et al. (2013) dan Sakkas et al. (2008). Pasien diberikan latihan intradialitik berupa mengayuh sepeda statis 
30-45 menit selama empat sampai enam bulan. Hasil penelitian menunjukan aerobic exercise dapat menurunkan skala RLS.

Latihan kekuatan merupakan salah satu jenis latihan fisik yang dibutuhkan pasien hemodialisis regular (da-Silva et al., 2013). Latihan kekuatan membuat otot lebih kuat dan bekerja lebih keras dengan melawan gaya resistensi. Kekuatan otot dibutuhkan dan merupakan dasar untuk melakukan kemampuan fisik yang lain. Penelitian yang dilakukan de-Lima et al. (2013) melaporkan dalam penelitiannya, streghthening exercise dapat meningkatkan kekuatan otot pernapasan, kapasitas fungsional, dan kualitas hidup pada pasien hemodialisis. Johansen (2000) merekomendasikan latihan kekuatan (strength traning) sebaiknya menjadi bagian rutin dari perawatan terapi hemodialisis untuk meningkatkan kualitas hidup pasien dialisis. Selain itu, Agency of Healthcare Research and Quality (2007) merekomendasikan pemberian latihan kekuatan pada ekstremitas bawah membantu mengurangi gejala RLS. Namun berdasarkan review literatur, latihan kekuatan belum dilakukan penelitian untuk mengetahui pengaruhnya dalam memperbaiki kondisi RLS. Berdasarkan temuan tersebut, latihan kekuatan memiliki potensi memperbaiki gejala RLS

Perawat memiliki peran dalam meningkatkan kualitas hidup pasien dengan mencegah komplikasi RLS pada pasien hemodialisis. Selain itu, perawat memiliki tugas dalam mendorong keberkelanjutan latihan fisik yang menjadi dasar pasien dalam melakukan aktifitas fisik (Bennett et al., 2013). Namun pelaksanaan program latihan di unit hemodialisis di Indonensia belum diterapkan. Program latihan fisik belum menjadi program protokol rutin bagi pasien hemodialisis di Indonesia. Latihan kekuatan sebagai salah satu jenis latihan fisik dalam penelitian sebelumnya berpengaruh positif bagi pasien hemodialisis dan merupakan salah satu bentuk intervensi keperawatan yang terdapat dalam standar Nursing Intervention Classification (2014) untuk meningkatkan aktivitas fisik pasien hemodialisis, namun belum diketahui pengaruh latihan kekuatan tersebut terhadap pasien hemodialisis yang mengalami RLS. Berdasarkan temuan literatur mengenai kekurangan penatalaksaan RLS yang telah dilakukan sebelumnya, pentingnya latihan fisik bagi pasien hemodialisis yang mengalami RLS dan studi pendahuluan yang dilakukan, dengan demikian menjadi penting untuk diteliti lebih lanjut mengenai pengaruh latihan kekuatan terhadap RLS pada pasien hemodialisis dan dapat dijadikan sebagai evidence based.

\section{Metode Penelitian}

Penelitian yang dilakukan menggunakan desain penelitian quasi eksperimen dengan pre-post test with control group design. Teknik pengambilan sampel pada penelitian ini menggunakan metode cluster random sampling dengan kriteria pasien yang telah menjalani hemodialisis rutin $>3$ bulan dan memiliki kriteria RLS, tidak memiliki riwayat fraktur ekstremitas bawah, dan tidak terpasang akses femoral. Sejumlah 32 pasien menjadi responden, yang terbagi menjadi kelompok intervensi sebanyak 15 responden dan kontrol 17 responden. Pengukuran skala RLS menggunakan International Restless Leg Syndrom (IRLS). International Restless Legs Scale berupa kuisioner yang terdiri dari 10 pertanyaan yang mencakup gejala dan efek terhadap perasaan dan kehidupan pasien. Setiap pertanyaan terdiri dari 5 poin. Skala yang terdapat pada IRLS terbagi menjadi 4 interval, yaitu sangat parah (31-40 poin), parah (21-30 poin), sedang (11-20), cukup (1-10 poin), tidak parah (0 poin) (IRLSSG, 2003). Data sekunder yang diambil adalah ureum, TIBC, adekuasi hemodialisis, terapi farmakologi, dan lamanya menjalani hemodialisis. Latihan kekuatan diberikan selama 8 minggu, 1 minggu sebanyak 2 kali saat proses hemodialisis. Gerakan terdiri dari penguatan otot lengan depan, ekstensi kaki dengan mengangkat kaki, menekuk lutut, serta penggunaan gelang beban pergelangan kaki dan tangan seberat $0,5 \mathrm{~kg}$.

\section{Hasil Penelitian}

Berdasarkan karekteristik umur dari 32 pasien, sebagian berada pada rentang dewasa akhir (43-65 tahun) yaitu sebanyak $80 \%$ pada kelompok intervensi dan $58,8 \%$ 
Anggriyana Tri Widianti : : Pengaruh Latihan Kekuatan terhadap Restless Legs Syndrom

Tabel 1 Kondisi RLS di Unit Hemodialisis RS Margono Soekardjo dan RSUD Banyumas setelah Dilakukan Latihan Kekuatan ( $\mathbf{N}=\mathbf{3 2})$

\begin{tabular}{lccc}
\hline \multicolumn{1}{c}{ Kelompok } & \multicolumn{3}{c}{ Kondisi RLS } \\
\hline $\begin{array}{l}\text { Intervensi } \\
(\mathrm{N}=15)\end{array}$ & Perbaikan & Tetap & Peningkatan Kondisi \\
$\begin{array}{l}\text { Kontrol } \\
(\mathrm{N}=17)\end{array}$ & $7(47 \%)$ & $3(20 \%)$ & $5(33 \%)$ \\
\hline
\end{tabular}

Tabel 2 Hasil Uji Statistik Skala RLS di Unit Hemodialisis RS Margono Soekardjo dan RS Banyumas Sebelum dan Setelah Dilakukan Latihan Kekuatan $(\mathbf{N}=32)$

\begin{tabular}{lccc}
\hline \multicolumn{1}{c}{ Variabel } & Intervensi $(\mathbf{N}=\mathbf{1 5})$ & Kontrol $(\mathbf{N}=\mathbf{1 7})$ & $p$-Value \\
\hline Skala RLS & mean \pm SD & mean \pm SD & \\
Pre intervensi & & & \\
Post Intervensi & $21,13 \pm 5,97$ & $22,03 \pm 4,47$ & 0,035 \\
$\Delta$ mean & $20,13 \pm 6,30$ & $23,29 \pm 5,25$ & \\
p valuec & $-1 \pm 3,38$ & $1,29 \pm 2,20$ & \\
\hline
\end{tabular}

pada kelompok kontrol 1. Ureum berada pada rentang $124,43 \pm 32,41$ di kelompok intervensi dan 139,39 \pm 59 , 82 di kelompok kontrol. Responden dalam kelompok kontrol lebih lama menjalani hemodialisis $(222 \pm 109,03)$ dibanding kelompok intervensi $(208 \pm 122,6)$. kelompok intervensi memiliki nilai TIBC kurang dari normal sebanyak 15 pasien (100\%), sedangkan kelompok kontrol sebanyak 5,9\%. Responden di kelompok intervensi lebih adekuat hemodialisis sebanyak $67 \%$, sedangkan kelompok kontrol hanya 58,8\%. Berdasarkan karekteristik jenis kelamin, sebagian besar pasien berjenis kelamin laki-laki yaitu sebanyak 20 orang (63\%). Kedua kelompok memiliki penyakit kormobid yang sama, yaitu hipertensi sebanyak 32 orang $(100 \%)$ dan diabetes sebanyak 4 orang (12,5\%). Obat yang diberikan kedua kelompok yaitu antihipertensi, asam folat dan erytopoeitin stimulating agent (ESA).

Pengaruh latihan kekuatan terhadap skala RLS pasien hemodialisis

Gambaran kondisi RLS di Unit Hemodialisis RSUD setelah dilakukan latihan kekuatan dapat dilihat pada tabel 1 .

Gambaran pengaruh dan perbedaan skala keparahan RLS di Unit Hemodialisis RSUD sebelum dan setelah dilakukan latihan kekuatan pada kelompok intervensi dapat dilihat pada tabel 2 .

\section{Pembahasan}

Hasil penelitian yang telah dilakukan, menunjukkan terdapat perbedaan yang bermakna secara statistik skala RLS pada kelompok intervensi dan kontrol $(p=0,035)$. Latihan kekuatan yang diberikan pada kelompok intervensi selama 8 minggu, menunjukkan adanya perbaikan dan mampu mempertahankan kondisi RLS di kelompok intervensi sebanyak $67 \%$ responden sedangkan pada kelompok kontrol 73\%. Peningkatan kondisi RLS menggambarkan semakin tidak baiknya RLS yang pasien alami. Hal ini menunjukkan terdapat penurunan skala setelah latihan kekuatan pada kelompok intervensi.

Temuan ini sejalan dengan penelitian sebelumnya. Hasil dalam penelitian ini didukung oleh penelitian yang dilakukan Esteves, de Mello, Benedito-Silva, Tufik (2011); Christoforos et al. (2010); dan Aukerman et al. (2006). Meskipun terdapat perbedaan dengan penelitian sebelumnya. Perbedaan penelitian tersebut dengan penelitian ini terdapat pada jenis latihan fisik yang diberikan dan durasi waktu pemberiannya. Latihan fisik yang diberikan 
berupa latihan aerobik sepeda ergometrik dan latihan tahanan (resistence) yang ternyata terbukti efektif mengurangi gejala RLS (Esteves et al., 2011, Christoforos et al., 2010; \& Aukerman et al., 2006).

Perbaikan pasien RLS pada kelompok intervensi dalam penelitian ini diperkuat dengan penjelasan bahwa aktivitas fisik berupa latihan kekuatan merupakan stimulus adaptasi fungsional dan metabolik pada neuromuskular. Latihan kekuatan memberikan hasil pada penguatan otot rangka dan peningatan kekuatan maksimal (Schiffer, Schulte, Hollmann, Bloch, \& Strüder, 2009). Latihan kekuatan juga telah terbukti memengaruhi fungsi kontrol motor (Graef, Michaelsen, Dadalt, Rodrigues, \& Pereira, 2014). Selama latihan fisik terjadi peningkatan aliran darah otak (Carvalho et al., 2015). Latihan kekuatan ini juga dapat menyeimbangkan produksi dopamin (Seifer, Brassard, Wissenberg, Rasmussen, Nordby, \& Stallknecht, 2010). Sedangkan pada pasien RLS memiliki karekteristik difisit dopamin yang menyebabkan gangguan motorik. Melalui ketrampilan motorik berupa skill exercise membantu dalam melakukan kontrol motor.

Mayoritas responden di kedua kelompok menunjukkan rentang skala kondisi RLS yang sedang sampai parah. Hal tersebut dapat ditunjukan dengan nilai mean 20,13 pada kelompok intervensi dan 23,29 pada kelompok kontrol. Review yang dilakukan Giannaki et al. (2013) menjelaskan faktor yang memengaruhi keparahan RLS yaitu hipertensi, jenis kelamin perempuan, peningkatan berat badan, lama melakukan hemodialisis, usia, dan diabetes mellitus.

Dalam penelitian ini menunjukkan data semua responden di kedua kelompok mengalami hipertensi, berada pada rentang usia dewasa akhir yang dapat memengaruhi peningkatan kondisi RLS selain disebabkan tingginya ureum. Pasien yang mengalami diabetes dikedua kelompok menunjukan peningkatan kondisi RLS. Hal tersebut sesuai dengan penjelasan Katsi et al. (2-14) dan Winter et al (2013). Winter et al. (2013) menjelaskan bahwa riwayat diabetes menjadi faktor risiko tinggi pasien mengalami RLS di Amerika. Berbeda dengan Pavan dan Satish (2013) yang melaporkan tingginya level
BUN tidak signifikan terhadap keparahan RLS. Adapun dalam penelitian ini, responden wanita di kelompok intervensi lebih menunjukkan perbaikan kondisi RLS karena rentang ureum yang lebih rendah. Responden wanita di kelompok kontrol menunjukan peningkatan kondisi RLS yang disebabkan kadar ureum yang tinggi.

Protokol latihan kekuatan pada penelitian ini merupakan salah satu yang mendukung keberhasilan intervensi. Gerakan latihan kekuatan yang diberikan dalam penelitian ini merujuk pada penelitian yang dilakukan oleh de Lima et al. (2013). Gerakan dalam latihan kekuatan yang diberikan dalam penelitian de Lima et al. (2013) terdiri dari 3 gerakan, dimana gerakan tersebut juga terdapat dalam prosedur latihan kekuatan Painter (2000). Meskipun RLS lebih sering terjadi pada tangan, namun gerakan pada tangan tersebut tetap diberikan. Hal ini ditujukan untuk mencegah peningkatan kondisi RLS yang dapat menyebar sampai ke area ekstremitas atas (Winkelman, 2006). Selama penelitian, peneliti tidak menemukan responden yang mengalami RLS pada ekstremitas atas. Selama responden diberikan intervensi, tidak terdapat responden yang mengalami proses pemberhentian hemodialisis, namun 2 responden mengalami kram kaki. Hal tersebut terjadi disebabkan oleh peningkatan QB pada mesin hemodialisis yang dinaikkan. Pemantauan tanda-tanda vital selalu dilakukan peneliti sebelum dan setelah intervensi diberikan. Pengukuran saturasi oksigen selalu termonitor selama melakukan intervensi. Selama diberikan intervensi, tidak terdapat nilai saturasi oksigen yang menurun dibawah normal dan pasien ratarata menunjukkan tekanan darah setelah diberikan perlakuan.

Pemberian berat beban yang diikatkan pada pergelangan tangan dan kaki, diberikan peneliti seberat $0,5 \mathrm{~kg}$. Peneliti mempertimbangkan untuk memberikan beban ringan $0,5 \mathrm{~kg}$ dan tidak menambah beban. Beberapa faktor yang memengaruhi kondisi pasien seperti kadar ureum yang tinggi, anemia di kedua kelompok sangat memengaruhi kondisi pasien hemodialisis.

Penelitian yang dilakukan de-Lima et al. (2013) pun memberikan efek positif terhadap kekuatan otot. Kekuatan otot responden 
Anggriyana Tri Widianti : : Pengaruh Latihan Kekuatan terhadap Restless Legs Syndrom

setelah perlakuan tidak diobservasi oleh peneliti, namun berdasarkan studi literatur bahwa kekuatan otot yang meningkat berpotensi memperbaiki kondisi RLS karena dengan peningkatan kekuatan otot akan berpengaruh terhadap kestabilan kontrol motor (Griffin \& Cafarelli, 2005). Sehingga berdasarkan hasil penelitian tersebut, peneliti mengambil gerakan minimal dalam prosedur latihan kekuatan namun tetap memberikan pengaruh terhadap RLS dalam penelitian ini.

Durasi atau lamanya pemberian intervensi, menentukan keoptimalan dari latihan kekuatan yang diberikan. Lamanya waktu sesi gerakan dan durasi penelitian ini mengacu pada penelitian yang dilakukan oleh Giannaki et al. (2010).

Latihan kekuatan dalam penelitian ini diberikan selama 8 minggu, sesuai dengan review penelitian-penelitian sebelumnya yang telah dilakukan. Pemilihan waktu selama 8 minggu sesuai dengan penelitian yang dilakukan oleh Giannaki et al. (2010). Penelitian lain melaporkan penurunan skala RLS setelah exercise terjadi setelah pemberian perlakuan dengan durasi waktu yang lebih lama yaitu 16 minggu yang dilakukan oleh Sakkas et al. (2008), 6 bulan oleh Mortazavi et al. (2013), dan Giannaki et al. (2013). Sehingga berdasarkan keefektifan waktu exercise tersebut, peneliti memilih waktu selama 8 minggu untuk dilakukan dalam penelitian ini

Smart dan Stelee (2013) melakukan review dosis pemberian latihan fisik bagi pasien gagal ginjal kronis yaitu 3 kali dalam seminggu. Dosis hemodialisis yang diberikan di Indonesia umumnya 2 kali seminggu. Smart dan Stelee (2013) merekomendasikan latihan fisik dalam jangka waktu lama yaitu 5 bulan baru dapat memberikan efek yang menguntungkan. Pedersen dan Saltin (2006) melakukan review dosis latihan fisik pada penyait kronis. Gagal ginjal kronis yang memiliki karekteristik pasien hampir sama dengan pasien gagal jantung kronik, akan didapatkan efek positif pada pasien jika melakukan latihan kekuatan selama 10 minggu sampai 5 bulan. Perbedaan rentang waktu dan dosis latihan fisik yang diberikan memengaruhi hasil dalam penelitian ini. Namun, dalam penelitian ini menunjukkan perbaikan pada kelompok intervensi selama 8 minggu perlakuan.

Karekteristik responden yang turut memengaruhi keoptimalan latihan kekuatan yang diberikan salah satunya adalah ureum. Berdasarkan data, responden yang mengalami perbaikan RLS dan kondisi tetap, memiliki kadar ureum kurang dari mean meskipun ureum menunjukan tidak berbeda antar kelompok. Peran ureum terhadap RLS dijelaskan melalui adanya toksisitas sistem saraf akibat tosksisitas uremik. Terdapat komplikasi peningkatan ureum terhadap perambatan neuron. Komplikasi tersebut yaitu polyneuropathy yang memengaruhi motorik, sensorik, saraf otonom, dan kranial. Hal ini memunculkan konduksi saraf yang abnormal sehingga mengakibatkan RLS (Brouns \& Deyna, 2004). Uremik neuropati berhubungan dengan proses demyelinating sekunder pada saraf tulang belakang sehingga memengaruhi refleks sensorik dan motorik yang melibatkan gerakan ekstremitas atas dan bawah (Rizzo et al., 2012). Myoklonus uremik yang muncul menimbulkan tipe gerakan seperti sindrom dengan kedutan dan kejang otot (Brouns \& Deyna, 2004).

Pada data hasil penelitian, telihat jelas dalam penelitian ini di kelompok intervensi memiliki TIBC kurang dari normal, namun mengalami perbaikan RLS. Sedangkan di kelompok kontrol, mayoritas nilai TIBC normal namun memiliki peningkatan kondisi RLS. Hasil dalam penelitian ini berbeda dengan studi yang dilakukan oleh Schultz (2011). Schultz (2011) melaporkan bahwa TIBC memiliki hubungan lemah terhadap RLS. Mizuno et al. (2005) menemukan bahwa zat besi di cairan serebrospinal, substansia nigra dan putamen, lebih rendah pada pasien RLS. Hasil penelitian tersebut menunjukkan bahwa pasien RLS memiliki disfungsi produksi dopamin yang disebabkan oleh kekurangan zat besi di area dopamin yang terkait tertentu dari otak. Zat besi dibutuhkan sebagai kofaktor tirosin hidroksilase yang merupakan tingkat pembatas produksi dopamin (Kavanagh, Siddiqui, \& Geddes, 2004). Yazdi et al. (2015) melaporkan tidak terdapat perbedaan kadar TIBC kelompok RLS dan non RLS. Sehingga perbedaan TIBC di masing-masing kelompok dalam 
penelitian ini belum dapat menggambarkan pengaruhnya terhadap perbaikan dan perburukan RLS.

Foley, Curtis, dan Parfley (2008) merekomendasikan target hemoglobin pasien hemodialisis pada rentang 10-12 g/dl yang menunjukan bahwa pasien hemodialisis memiliki kondisi yang baik. Rentang hemoglobin tersebut juga menunjukkan toleransi pasien terhadap exercise dan kemampuan fungsional.

Responden di kedua kelompok pada penelitian ini memiliki hipertensi sebagai penyakit kormobid yang umum dialami. Penyakit kormobid yang terdapat di kelompok kontrol, yaitu hipertensi $(100 \%)$, diabetes $(11 \%)$, stroke $(5,8 \%)$, dan kardiomegali $(5,8 \%)$. Adapun responden di kelompok intervensi hanya memiliki penyakit kormobid berupa hipertensi $(100 \%)$ dan diabetes $(13,3 \%)$. Temuan pada penelitian ini sejalan dengan penelitian yang dilakukan oleh Winter et al. (2013). Winter et al. (2013) melakukan penelitian di Amerika, melaporkan diabetes secara signifikan meningkatkan kemungkinan terjadinya RLS. Tidak terkontrol gula darah tinggi pada pasien diabetes dapat menyebabkan kerusakan saraf yang dapat menyebabkan diabetik neuropati perifer.

Pasien yang mengalami RLS dapat disertai dengan penyakit kardiovaskuler dan stroke. Aktivasi otonom terjadi beberapa detik untuk memulai gerakan pada RLS yang menyebabkan peningkatan aktivasi simpatik melebihi ambang batas tertentu yang menstimulasi RLS. Hal ini merupakan alasan rasional terjadinya pengulangan perubahan tekanan darah malam hari dan dilanjutkan peningkatan tekanan darah siang harinya, inilah yang menyebabkan peningkatan aktivitas simpatik yang dihubungkan dengan hipertensi dan penyakit kardiovaskuler (Katsi et al., 2014). Peningkatan tekanan darah dapat meningkatkan koagulabilitas dan risiko pembentukan plak aterosklerosis dan pecah, hal inilah yang dihubungkan dengan kejadian Stroke. Selain itu, RLS dapat menyebabkan apnea saat tidur yang menyebabkan stroke dan penyakit kardiovaskular lainnya (Katsi et al., 2014).

Responden dalam penelitian ini berkisar pada usia 27 tahun sampai 64 tahun. Berdasarkan data penelitian ini, mayoritas uremik RLS dialami pada usia dewasa akhir. Hal ini dijelaskan bahwa kejadian RLS meningkat seiring dengan semakin meningkatnya usia. Hasil penelitian ini sesuai dengan hasil penelitian sebelumnya. Meningkatnya usia sebagai faktor risiko terjadinya uremik RLS. Çurgunlu et al. (2012) dalam studinya melaporkan RLS lebih parah dan seiring meningkatnya disebabkan oleh defisiensi besi yang terlihat dari rendahnya level ferritin.

Keoptimalan latihan kekuatan yang diberikan dapat dipengaruhi faktor adekuasi hemodialisis meskipun antar kelompok tidak memiliki perbedaan bermakna secara statistik. Data dalam penelitian ini menunjukan kelompok intervensi memiliki keadekuatan hemodialisis. Adekuasi hemodialisis merupakan faktor yang tidak berhubungan dengan RLS namun berkaitan dengan kualitas hidup pasien hemodialisis terhadap komplikasi yang dapat terjadi. Haider, Anees, dan Shahid (2014) yang menyebutkan penyebab tingginya frekuensi RLS salah satunya adalah inadekuat hemodialisis. Menyediakan dialisis yang adekuat pada pasien gagal ginjal kronis penting dalam pemenuhan dialisis inadekuat yang dapat meurunkan morbiditas dan mortalitas.

Kelompok intervensi dan kontrol tidak memiliki perbedaan durasi lama menjalani hemodialisis. Kelompok kontrol memiliki durasi hemodialisis yang lebih lama. Hal ini dapat menguatkan semakin lamanya durasi hemodialisis dapat memperburuk keadaan RLS. Beladi-Mousavi et al. (2015) menemukan hubungan antara durasi dialisis dan munculnya RLS. Hubungan ini dikaitkan dengan risiko berkembangnya RLS. Hal ini berhubungan dengan makin progresifnya gejala dan penyakit yang mendasari terapi dialisis pada penderita yang menjalani hemodialisis dalam waktu yang lama.

Terdapat responden di kedua kelompok yang mengalami peningkatan kondisi RLS. Peningkatan kondisi RLS ini berada pada katagori skala RLS yang parah. Peningkatan kondisi RLS tersebut oleh peneliti dilakukan monitor tanda-tanda vital berupa tekanan darah, RR, nadi dan saturasi oksigen. Hal ini ditujukan untuk memastikan keamanan 
Anggriyana Tri Widianti : : Pengaruh Latihan Kekuatan terhadap Restless Legs Syndrom

latihan kekuatan yang diberikan terhadap kondisi pasien.

\section{Simpulan}

Kelompok intervensi menunjukan skala RLS posttest lebih rendah dari skala pretest dibandingkan kelompok kontrol, hal ini menunjukan terdapat perbaikan RLS di kelompok intervensi setelah diberikan latihan kekuatan skala RLS posttest di kelompok kontrol terlihat lebih meningkat dari pretest dan menunjukan peningkatan kondisi. Hal ini menunjukkan kelompok intervensi terlihat membaik setelah diberikan latihan kekuatan selama 8 minggu. Sedangkan kelompok kontrol terjadi peningkatan kondisi RLS karena terjadi peningkatan skala RLS. Hal tersebut menyimpukan bahwa latihan kekuatan memberikan pengaruh terhadap perbaikan kondisi RLS pada pasien hemodialisis.

\section{Daftar Pustaka}

Agency of Healthcare Research and Quality. (2007). National Healthcare Quality Report. U.S. Department of Health and Human Service.

Aukerman, M.M., Aukerman, D., Bayard, M., Tudiver, F., Thorp, L., \& Bailey, B. (2006). Exercise and restless legs syndrome: A randomized controlled trial. J Am Board Fam Med, 19, 487-93.

Baradero, M. (2005). Klien gangguan ginjal: seri asuhan keperawatan. Jakarta: EGC.

Beladi-Mousavi, S.S., Jafarizade, M., Shayanpour, S., Bahadoram, M., Moosavian, S.S.M., \& Houshmand, G. (2015). Restless legs syndrome: Associated risk factors in hemodialysis patients. Nephro Urol Mon, 7(6), e31967.

Bennett, P.N., Breugelmans, L., Barnard, R., Agius, M., Chan, D., Fraser, D., . . . Potter, L. (2013). Sustaining a hemodialysis exercise program: A review. Seminars in Dialysis, 23. doi: 10.1111/j.1525-139X.2009.00652.x.
Brouns, R., \& Deyn, P.P.D. (2004). Neurological complications in renal failure: A review. Clinical Neurology and Neurosurgery, 107.

Carvalho, A., Barbirato, D., Araujo, A., Martins, J.V., Cavalcanti, J.J.S., Santos, J.M., ..., Deslandes, A.C. (2015). Comparison of strength training, aerobic training, and additional physical therapy as supplementary treatments for Parkinson's disease: Pilot study. Clinical Interventions in Aging, 10, 183-191.

Centers for Disease Control and Prevention (CDC). (2014). National chronic kidney disease fact sheet: General information and national estimates on chronic kidney disease in the united states, 2014. Atlanta, GA: US Department of Health and Human Services, Centers for Disease Control and Prevention; 2014.

Christoforos, D.G., Georgios, M.H., Christina, K., Maria, D.M., Yiannis K., Paraskevi, F., ..., Ioannis, S. (2010). A single-blind randomized controlled trial to evaluate the effect of 6 months of progressive aerobic exercise training in patients with uraemic restless legs syndrome. ASAIO Journal, 56, 538-542. DOI: 10.1097/MAT.0b013e3181f1cc04.

Çurgunlu, A., Döventaş, A., Karadeniz, D., Erdinçler, D.S., Oztürk, A.K., Karter, Y., \& Beğer, T. (2012). Prevalence and characteristics of restless legs syndrome (RLS) in the elderly and the relation of serum ferritin levels with disease severity: hospitalbased study from Istanbul, Turkey. Arch Gerontol Geriatr, 55(1), 73-6. doi: 10.1016/j. archger.2011.06.002.

de-Lima, M.C., Cicotoste, C., Cardoso, K.D., Junior, L.G.F., Monteiro, M.B., \& Dias AS. (2013). Effect of exercise performed during hemodialysis: Strength versus Aerobic. Renal Failure, 35(5), 697-704.

da-Silva, S.F., Pereira, A.A., Aparecido, W., Silva, H., d., Simôes, R., Barros, J., d. R., \& Neto. (2013). Physical therapy during hemodialyse in patients with chronic kidney disease. J Bras Nefrol, 35. doi: 10.5935/0101- 
2800.20130028 .

Esteves, E.M., de Mello, M.T., BeneditoSilva, A.A., \& Tufik, S. (2011). Impact of aerobic physical exercise on Restless Legs Syndrome. Sleep Sci, 4(2), 45-48.

Foley, R.N., Curtis, B.M., \& Parfrey, P.S. (2008). Hemoglobin targets and blood transfusions in hemodialysis patients without symptomatic cardiac disease receiving erythropoietin therapy. Clin $J \mathrm{Am}$ Soc Nephrol, 3(6), 1669-1675. Doi: 10.2215/ CJN.02100508.

Giannaki, C.D., Sakkas, G.K., Karatzaferi, C., Hadjigeorgiou, G.M., \& Lavdas, E. (2010) Evidence of increased muscle atrophy and impaired quality of life parameters in patients with uremic restless legs syndrome. PLoS ONE, 6(10), e25180. doi:10.1371/ journal.pone.0025180.

Giannaki, C.D., Zigoulis, P., \& Karatzaferi C. (2013). Periodic limb movements in sleep contribute to further cardiac structure abnormalities in hemodialysis patients with restless legs syndrome. J Clin Sleep Med, 9, 147-153.

Giannaki, C.D., Sakkas, G.K., Hadjigeorgiou, G.M., Karatzaferi, K., Patramani, G., \& Lavdas, E. 2010). Non-pharmacological management of periodic limb movements during hemodialysis session in patients with uremic restless legs syndrome. ASAIO Journal, 56, 538-542.

Graef, P., Michaelsen, S.M., Dadalt, M.L.R., Rodrigues, D.A.M.S., \& Pereira, F. (2014). Effects of functional and analytical strength training on upper-extremity activity after stroke: A randomized controlled trial. Braz J Phys Ther, 1-3

Griffin,L., Cafarelli, E. (2005). Resistence training: cortical, spinal and motor unit adaptation.Can.J.Appl.Phsiol.30(3):328-340.

Haider, I.,Anees, M., \& Shahid, S.A.H.(2014). Restless legs syndrome in end stage renal disease patients on haemodialysis. Pak J Med Sci, 30(6), 1209-1212. doi: http://dx.doi. org/10.12669/pjms.306.5691.

The International Restless Legs Syndrome Study Group.(2003). Validation of the International Restless Legs Syndrome Study Group rating scale for restless legs syndrome. Sleep Medicine, 4, 121-132.

Jaber, B. L., Schiller, B., Burkart, J. M., Daoui, R., Kraus, M. A., Lee, Y., ..., Finkelstein, F.O. (2011). Impact of short daily hemodialysis on restless legs symptoms and sleep disturbances. Clin J Am Soc Nephrol, 6. doi: $10.2215 /$ CJN.10451110.

Johansen, K.L., \& Painter, P. (2012). Exercise in individuals with CKD. Am J Kidney Dis, 59, 126-134.

Katsi, V., Katsimichas, T., Kallistratos, M.S., Tsekoura, D., Makris, T., Manolis, A.J., Tousoulis, ..., Kallikazaros, I. (2014). The association of Restless Legs Syndrome with hypertension and cardiovascular disease. Med Sci Monit, 20, 654-659.

Kavanagh, D., Siddiqui, S., \& Geddes, C.C. (2004). Restless legs syndrome in patients on dialysis. Am J Kidney Dis, 43, 763-771.

Lazano, R., Naghavi, M., Foreman, K., Lim, S., Shibuya, K., Aboyans, ..., Adair, I. (2012). Global and regional mortality from 235 causes of death for 20 age groups in 1990 and2010: A systematic analysis for the Global Burden.

Mizuno S., Mihara T., Miyaoka T., Inagaki T., \& Horiguchi J. (2005). CSF iron, ferritin and transferrin levels in restless legs syndrome. $J$. Sleep Res, 14, 43-47.

Mortazavi, M.,Vahdatpour, B.,Ghasempour, A.,Taheri, D., Shahidi, S., \& Moeinzadeh, F. (2013). Aerobic exercise improves signs of restless leg syndrome in end stage renal disease patients suffering chronic hemodialysis. The Scientific World Journal, $1-4$.

Özkan, G., \& Ulusoy, S. (2011). Acute complications of hemodialysis, technical problems in patients on hemodialysis, Prof. 
Maria Goretti Penido (Ed.). ISBN: 978-953307-403-0, InTech.

Painter, P. (2000). Exercise, a guide for the people on dialysis. Medical Education Institute, Inc

Pavan, M., Sathish, J.(2013). Restless legs syndrome in patients on chronic hemodialysis. Dial Traspl. 35(1):3-6.

Pedersen, B.K., \& Saltin, B.(2006). Review: Evidence for prescribing exercise as therapy in chronic disease. Scand J Med Sci Sports, 16(Suppl. 1), 3-63.

Perkumpulan Nefrologi Indonesia (PERNEFRI). (2014). 7th Report Of Indonesian Renal Registry.

Rizzo, M.A., Frediani, F., Granata, A., Ravasi., B., Cusi, D., \& Gallieni, M. (2012). Neurological complications of hemodialysis: State of the art. JNEPHROL, 25(02), 170182. DOI: $10.5301 /$ jn. 5000087.

Restless Legs Syndrome Foundation. (2008). Restless legs syndrome 2008. The RLS Foundation.

Sakkas, G.S., Hadjigeorgiou, G.M., Karatzaferi, K., Maridaki, M.D., Giannaki, C.D., \& Mertens, P.R. (2008). Intradialytic aerobic exercise training ameliorates symptoms of restless legs syndrome and improves functional capacity In patients on hemodialysis. ASAIO Journal, 54, 185-190.

Schiffer, T., Schulte, S., Hollmann, W., Bloch, W., \& Strüder, H.K. (2009). Effects of strength and endurance training on brainderived neurotrophic factor and insulin-like growth factor 1 in humans. Horm Metab Res, $41,250-254$.

Schultz. (2011). Determinants of periodic limb movements in sleep within patients with restless legs syndrome (Thesis). Rollins School of Public Health of Emory University.

Seifer, T., Brassard, P., Wissenberg, M., Rasmussen, P., Nordby, P., Stallknecht, B., ..., Secher, N.H. (2010). Endurance training enhances BDNF release from the human brain. Am J Physiol Regul Integr Comp Physiol, 298, R372-R377.

Smart, N., \& Stelee, M. (2011). Exercise training in haemodialysis patients: A systematic review and meta-analysis. Nephrology, 16, 626-632. doi:10.1111/ j.1440-1797.2011.01471.x.

Symvoulakis, E., Anyfantakis, D., \& Lionis, I.C. (2010). Restless legs syndrome: Literature review. Sao Paulo Med J, 128.

Tandi, M., Mongan, A., \& Manoppo, F. (2014). Hubungan antara derajat penyakit ginjal kronik dengan nilai agregasi trombosit di rsup prof. Dr. R. D. Kandou manado. Jurnal e-Biomedik (eBM), 2.

Winkelmann, J. (2006). Complex segregation analysis of restless legs syndrome provides evidence for an autosomal dominant mode of inheritance in early age at onset families. Ann Neurol, 52, 297-302.

Winter, A.C., Berger, K., Glynn, R.J., Buring, J.E., Gaziano, M., Schürks, M.S., \& Kurth, T. (2013). Vascular risk factors, cardiovascular disease and restless legs syndrome in men. $\mathrm{Am}$ J Med., 126(3), 228-235.e2. doi:10.1016/j. amjmed.2012.06.039.

Yazdi, Z., Sadeghniiat-Haghighi, K., Kazemifar, A.M., Kordi, A., \& Naghipour, S. (2015). Restless leg syndrome in hemodialysis patients: A disorder that should be noticed. Saudi J Kidney Dis Transpl, 26(3), 625-630. 